\title{
Short communication: Diversity of staphylococci isolated from sheep mastitis in northern Algeria
}

\author{
Rachid Achek, ${ }^{1,2}$ Hosny El-Adawy, ${ }^{3,4 *}$ ๑ Helmut Hotzel, ${ }^{4}$ Herbert Tomaso, ${ }^{4}$ Ralf Ehricht, ${ }^{5,6}$ \\ Taha Mossadak Hamdi, ${ }^{2}$ Omar Azzi, ${ }^{2}$ and Stefan Monecke ${ }^{5,6,7}$ \\ ${ }^{1}$ Faculty of Nature and Life and Earth Sciences, Djilali-Bounaama University, Soufay, 44225 Khemis-Miliana, Algeria \\ ${ }^{2}$ Laboratory of Food Hygiene and Quality Assurance System, High National Veterinary School, Oued Smar, Algiers, Algeria \\ ${ }^{3}$ Friedrich-Loeffler-Institut, Institute of Bacterial Infections and Zoonoses, 07743 Jena, Germany \\ ${ }^{4}$ Department of Poultry Diseases, Faculty of Veterinary Medicine, Kafrelsheikh University, 35516 Kafr El-Sheikh, Egypt \\ ${ }^{5}$ Leibniz Institute of Photonic Technology (IPHT), 07745 Jena, Germany \\ ${ }^{6}$ InfectoGnostics Research Campus Jena e. V., 07743 Jena, Germany \\ ${ }^{7}$ Institute for Medical Microbiology and Hygiene, Medical Faculty "Carl Gustav Carus," Technical University Dresden, 01307 Dresden, Germany
}

\begin{abstract}
Mastitis in ruminants is an important disease with major effects on both the economy and animal welfare. It is caused by major pathogens such as Staphylococcus aureus and minor pathogens such as coagulase-negative staphylococci. The objective of this study was to identify and characterize staphylococci as a cause of sheep mastitis in Algeria. In this study, 123 milk samples were collected directly from the udder of sheep suffering from clinical mastitis in 2 provinces in Algeria. Recovered isolates were identified using MALDI-TOF mass spectrometry. Virulence-associated and antimicrobial resistance genes as well as clonal complexes (CC) of $S$. aureus were determined using microarray-based analysis. A total of 45 staphylococci isolates were cultivated from sheep milk samples, and $28 S$. aureus were identified as methicillin susceptible $(62.2 \%)$. Seventeen other Staphylococcus isolates of different species were identified using MALDI-TOF mass spectrometry. Subsequent microarray analysis typed the methicillin-susceptible $S$. aureus to 6 CC: CC8-MSSA, CC97-MSSA, CC130/521-MSSA, CC479-MSSA, CC522-MSSA, and CC705-MSSA. The accessory gene regulator agrIII and the ruminant leukocidin genes $l u k \mathrm{~F}-\mathrm{P} 83$ and $l u k \mathrm{M}$ were found in all isolates of CC130/521, CC479, CC522, and CC705. The toxic shock syndrome toxin gene tst1 was detected exclusively in CC130/521. Additionally, virulence-associated genes (sea, sed, sak, hld, hlgA, edin $\mathrm{B}$, and others) were detected. The presence of antibiotic resistance genes [blaZ, $\operatorname{erm}(\mathrm{B})$, and $\operatorname{tet}(\mathrm{K})]$ was detected in small numbers of staphylococci. Staphylococci possessing these genes are considered potential hazards for
\end{abstract}

Received March 8, 2019.

Accepted September 5, 2019.

*Corresponding author: hosny.eladawy@fli.de farm animals, farmers, and consumers. Data concerning the prevalence and diversity of staphylococci causing mastitis in sheep from Algeria are lacking. Presented results on different aspects about staphylococci in Algerian sheep populations should at least partially close that gap. However, further extensive studies covering more geographical regions are needed to assess the epidemiological risk.

Key words: Staphylococcus, sheep mastitis, microarray, Algeria

\section{Short Communication}

Mastitis is an inflammatory infection of the mammary gland that can be caused by several species of bacteria classified into 3 groups: environmental, contagious, and opportunistic pathogens. In sheep farming, mastitis is the most relevant pathology at the herd level, resulting in economic consequences (Gonzalo et al., 2002; Leitner et al., 2008; Giadinis et al., 2012). Important causative agents of ovine mastitis include diverse microorganisms such as staphylococci, Mannheimia haemolytica, Escherichia coli, and various streptococci. Coagulasenegative staphylococci have also been confirmed as an etiological agent of bacterial mastitis in sheep (Dore et al., 2016). Staphylococcus aureus is the most common agent of subclinical or clinical mastitis in sheep (Menzies and Ramanoon, 2001; Gonzalo et al., 2004; Mørk et al., 2005; Mavrogianni et al., 2011). The pathogenicity of this bacterium is mainly related to its capacity to encode and produce a multitude of virulence factors (Chua et al., 2014; McMillan et al., 2016).

Several therapeutic regimens are used to treat mastitis in ruminants. However, extensive use of antibiotics may favor the selection of resistant strains within $S$. aureus populations (Kennedy et al., 2008). The spread of antimicrobial resistance in $S$. aureus isolated from 
sheep mastitis has been reported in many studies (Mørk et al., 2005; Lollai et al., 2008; Carfora et al., 2016). Although methicillin is not used for treatment of mastitis in sheep, methicillin-resistant $S$. aureus (MRSA) has been recovered in sheep milk (Carfora et al., 2016; Caruso et al., 2016; Obaidat et al., 2018) and from cases of sheep mastitis (Goñi et al., 2004; Mørk et al., 2005; Vautor et al., 2007; Azara et al., 2017b).

Clinical mastitis is usually diagnosed via clinical examination, and the causative pathogen is identified by isolation and biochemical identification (Mavrogianni et al., 2011). Staphylococcus aureus isolated from clinical mastitis were identified using microbiological and molecular methods (Oliver, 2004; Viguier et al., 2009). Genotyping of $S$. aureus isolates is important for studying the dissemination of this pathogen in flocks (Porrero et al., 2012; Smith et al., 2014; Azara et al., 2017b).

DNA microarrays have been used to genotype Staphylococcus strains, to investigate carriage of multiple virulence-associated genes, and to give reliable information about the clonal diversity of $S$. aureus isolates (Monecke et al., 2007; El-Adawy et al., 2016). Commonly detected clonal complexes (CC) of $S$. aureus in sheep mastitis are CC130, CC133, and CC522 (Smyth et al., 2009; Porrero et al., 2012).

In Algeria, antimicrobial susceptibility patterns of $S$. aureus are widely investigated in hospital and human population infections (Ramdani-Bouguessa et al., 2006; Ouchenane et al., 2011; Rebiahi et al., 2011). Despite a previous study describing the prevalence and epidemiology of $S$. aureus in sheep (Agabou et al., 2017), little information is available about the genetic diversity of MRSA and methicillin-susceptible S. aureus (MSSA) strains isolated from mastitis-diseased sheep in Algeria. This study aimed to investigate the genetic diversity of Staphylococcus isolates collected from sheep with mastitis in 2 provinces of Algeria using microarray-based technology.

Sheep are important animals in Algerian livestock production with regard to meat production. The Algerian system of sheep breeding estimates a total number of 28 million heads (FAO, 2015) and provides $50 \%$ of Algerian red meat (Harkat et al., 2015). The majority of Algerian herds of sheep are concentrated in the high plains region located between 2 mountain ranges (The Hill Atlas and Sahara Atlas). About $60 \%$ of all Algerian sheep belong to the Ouled Djellal breed, representing the principal local sheep breed in Algeria with a number exceeding 11,340,000 heads. Algerian sheep are also used for wool production. Sheep milk is used for feeding lambs and is commonly consumed by the farmer. There is a lack of sophisticated milk production systems or of any dairy industry in this field. Production effective- ness is primarily disturbed by the occurrence of several diseases affecting health and welfare.

The 2 provinces where the study was conducted (Médéa and Ain Defla) are situated in the north of Algeria and occupy an area of $13,757 \mathrm{~km}^{2}$. The total number of sheep in these areas was estimated at 860,000 (representing $3.05 \%$ of Algerian sheep), and the total number of small-scale sheep farms (capacity of 10-250 heads per farm) was estimated at 12,000. The sheep breeds raised in the area of study are appreciated for their maternal aptitudes and prolificacy. Selection of the participating farms for the study depended on acceptance of the farmers, age of sheep (1 yr or older at different stages of lactation), and presence of clinical mastitis during the lambing season (October 2017 to January 2018). The total number of herds in the area of study and the number of heads in the selected farms are presented in Supplemental Tables S1, S2, S3, and S4 (https://doi.org/10.3168/jds.2019-16583). The number of sheep represents almost $50 \%$ of all heads existing in the farm (sheep, ewes, rams, lambs), in which sheep producing milk for feed lambs or for domestic consumption represent $30 \%$. It is difficult to determine the exact number of lactating sheep due to the farmers periodically changing the flocks (by selling and purchasing new sheep), the death of sheep caused by existing viral diseases, and according to the trans-human breeding mode through seasonal movement of livestock (pastoralism or nomadism).

In this study, the milk samples were collected during the lambing season from October 2017 to January 2018. Sheep included in this study were 1 yr of age or older and at different stages of lactation, and they were kept in open stables in small-scale farms. They showed clinical symptoms of acute mastitis. Ovine mastitis cases were clinically diagnosed by the following symptoms: fever, edema, anorexia with flock abandonment or suckling refuse, udder pain, consistency or discoloration of udder, watery milk, and bloody secretion.

A total of 123 milk samples were aseptically collected from 110 sheep farms in Algeria, either by members of the research team (83 samples) or by private veterinarians (40 samples) who were properly trained to collect milk samples for this study. Briefly, teats were disinfected using hydrophilic cotton saturated with $70 \%$ ethanol and dried with disposable sterile compresses. All samples were collected before using any antibiotic treatment on the sheep. The first milk squirts were discarded, and 4 to $5 \mathrm{~mL}$ of milk was collected in sterile tubes. A visual examination to detect the presence of blood, pus, and so on followed, and the milk was transported in ice-cooled containers to the microbiology laboratory, Faculty of Sciences, Yahia Farès University of Médéa (Algeria). Samples were kept frozen on site 
and stored at $-20^{\circ} \mathrm{C}$ for preservation until submission to the laboratory for microbiological investigations.

Staphylococci were isolated and identified according to routine procedures in the laboratory by using different culture media for isolation (Columbia blood agar), purification (mannitol salt agar), preservation (brain heart infusion broth supplemented with glycerol), and selection (Baird-Parker agar). Bacteriological analyses were performed according to conventional methods (International Dairy Federation, 1981) modified by Oliver (2004). One milliliter of milk sample was mixed with 9 $\mathrm{mL}$ of brain heart infusion broth (BioMérieux, Marcy l'Étoile, France) and incubated at $37^{\circ} \mathrm{C}$ for $24 \mathrm{~h}$ for enrichment. A total of $100 \mu \mathrm{L}$ of broth culture was streaked on Columbia agar (Oxoid Ltd., Basingstoke, UK) supplemented with $5 \%$ of sheep blood and incubated at $37^{\circ} \mathrm{C}$ for 24 to $48 \mathrm{~h}$. All growing colonies were picked and subcultured onto mannitol salt agar (Oxoid Ltd.). Pure colonies on mannitol salt agar were subjected to Gram staining, catalase, and coagulase tests according to standard microbiological methods (Quinn et al., 1994). Identified colonies were picked and suspended into cryotubes containing brain heart infusion broth with $30 \%$ of glycerol medium, which was used for long-term storage (i.e., freezing). All bacterial isolates were recultivated on Baird-Parker agar (Sifin, Berlin, Germany). After subculturing on Müller-Hinton blood agar (Oxoid Ltd.), all suspected bacterial colonies were identified using MALDI-TOF MS. Spectra were acquired with an Ultraflex instrument (Bruker Daltonik GmbH, Bremen, Germany). Analysis was done using Biotyper 3.1 software (Bruker Daltonik GmbH; ElAshker et al., 2015).

Genomic bacterial DNA was extracted from bacterial cultures on Baird-Parker agar using a High Pure PCR Template Purification Kit (Roche Diagnostics GmbH, Mannheim, Germany) according to the manufacturer's instructions. Additionally, lysostaphin was applied for DNA extraction. DNA was stored at $-20^{\circ} \mathrm{C}$ until further analyses.

Microarray analysis was carried out for all staphylococci using the StaphyType Kit (Alere Technologies GmbH, Jena, Germany). Targets, protocols, and data interpretation have been described previously (Monecke and Ehricht, 2005; Monecke et al., 2008). Images of the microarrays were automatically analyzed using a designated reader and software (Alere Technologies $\mathrm{GmbH}$ ).

Out of 123 sheep milk samples, 41 were positive for staphylococci (33.3\%). Some of the positive milk samples yielded 2 staphylococcal species, resulting in a total of 45 isolates. Twenty-eight Staphylococcus isolates $(62.2 \%)$ were identified as methicillin-sensitive $S$. aureus. These findings were in agreement with previous reports confirming that staphylococci were the most common microorganisms isolated from clinical and subclinical cases of mastitis in sheep (Bergonier et al., 2003; Arsenault et al., 2008).

Using microarray-based analysis, MSSA were assigned to 6 CC: CC8-MSSA, CC97-MSSA, CC130/521-MSSA, CC479-MSSA, CC522-MSSA, and CC705-MSSA. The most common type was CC130/521, with 18 out of 28 S. aureus isolates (64.3\%); CC522 was detected 4 times, CC8 and CC479 were detected twice each, and CC97 and CC705 were found once each.

The microarray assay used in this study was specifically developed for analysis of $S$. aureus isolates. The microarray system does not cover genes and alleles from NAS. Only resistance genes are an exception because they are conserved across species. Thus, the data about NAS are not comparable with $S$. aureus results.

This finding was in accordance with previous studies that indicated that CC130-MSSA appears to be a common lineage in sheep causing several infections (Monecke et al., 2016; Agabou et al., 2017). In connection with mastitis, CC130 was widely spread among $S$. aureus isolates from sheep in Italy (Carfora et al., 2016; Azara et al., 2017b) and in Switzerland (Merz et al., 2016). The predominance of $S$. aureus strains assigned to CC130 suggests that this clone may have special characteristics to overcome host defense mechanisms and to cause an IMI in sheep (Vautor et al., 2005). Akkou et al. (2018) found the predominance of CC130 also in caprine mastitis among cases from the same region of northern Algeria (Akkou et al., 2018). The observation from this study was in accordance with previous reports that indicated that staphylococci from sheep and goats were genetically related but different from human and bovine isolates (Ben Zakour et al., 2008; Smith et al., 2014).

Staphylococcus aureus isolates belonging to CC97 have been previously observed among nasal samples of sheep from Algeria (Agabou et al., 2017) and Tunisia (Gharsa et al., 2012) and from ovine bulk milk in Switzerland (Merz et al., 2016). In addition, CC97 is frequently detected in cattle (Monecke et al., 2007; BarGal et al., 2015). Monecke et al. (2016) reported that CC8, CC97, and CC130 were present among S. aureus isolates in wildlife.

In Algeria, Agabou et al. (2017) reported the isolation of $S$. aureus $\mathrm{CC} 8$ from humans and sheep. The detection of CC (e.g., CC8) in humans and animals (e.g., sheep) suggests a possible transmission from humans to their domestic animals and vice versa (Schaumburg et al., 2015).

In this study, only 1 MSSA belonged to CC479. This clone was mainly associated with bovine $S$. aureus isolates (Artursson et al., 2016). Ben Zakour et al. (2008) found that some bovine strains were genetically related 
to the common ovine $S$. aureus lineage as ST133, suggesting that a similar set of virulence-associated genes may be required for bovine and ovine mastitis. The detection of this bovine CC among sheep mastitis isolates can be explained by the fact that sheep and cattle are largely farmed in Algeria together. Four isolates were assigned to CC522. It was previously reported that ovine $S$. aureus isolates mainly belong to CC133 and CC522 (Smith et al., 2014), with CC522 mostly being restricted to Africa and southern Europe.

Capsule type 8 and capsule type 5 were detected in 4 and $2 \mathrm{CC}$ of $S$. aureus, respectively (Table 1 ). In 1 milk sample, S. aureus was detected together with Staphylococcus saprophyticus. In addition to $S$. aureus, other staphylococcal species that were found were identified using MALDI-TOF MS: S. saprophyticus $(7 \times)$, S. cohnii $(2 \times)$, and $S$. chromogenes, S. haemolyticus, S. nepalensis, S. sciuri, S. simulans, S. succinus, S. warneri, and $S$. xylosus $(1 \times$ each). One milk sample harbored S. cohnii as well as $S$. saprophyticus, and S. cohnii, S. chromogenes, and S. saprophyticus were cultivated and identified from another sample.

Mastitis is an intramammary inflammation determined by the nature and virulence factors of bacteria or groups of them, further promoted by antibiotic resistance and other host factors (Gelasakis et al., 2015). It has been reported that certain virulence genes are overrepresented in some clonal lineages and that some combinations are correlated with high pathogenic potential (van Belkum et al., 2006). Microarray analysis of $S$. aureus isolates (Table 1) revealed other relevant information besides the CC. In this study, several bacterial virulence factors were detected as immune evasion factors, adhesion factors, pore-forming toxins, superantigens, and antibiotic resistance determinants. Virulence factors of $S$. aureus were associated with the 4 groups that were assigned based on the accessory gene regulator (agr; Vautor et al., 2007). The accessory gene regulator alleles agrIII and $a g r I$ were predominant because they were present in all CC130/521 isolates $(18 / 28 ; 64.3 \%)$, which agrees with $S$. aureus isolates from milk of ewes with mastitis and from the nostrils of sheep. They were also mainly assigned to agr groups I (44\%) or III (46\%; Vautor et al., 2007). The ruminant leukocidin genes $l u k \mathrm{~F}-\mathrm{P} 83$ and $l u k \mathrm{M}$ were found in all isolates of CC130/521, CC479, CC522, and CC705, whereas genes coding for the human-specific bi-component cytotoxin Panton-Valentine leukocidin $l u k \mathrm{~F} / \mathrm{S}-\mathrm{PVL}$ were not found in any of the isolates. The toxic shock syndrome toxin gene tst1 was detected exclusively in CC130/521 S. aureus isolates (Table 1). The sea gene was detected in 4 out of 18 CC130/521 and 3 out of 4 CC522 S. aureus isolates. One of the

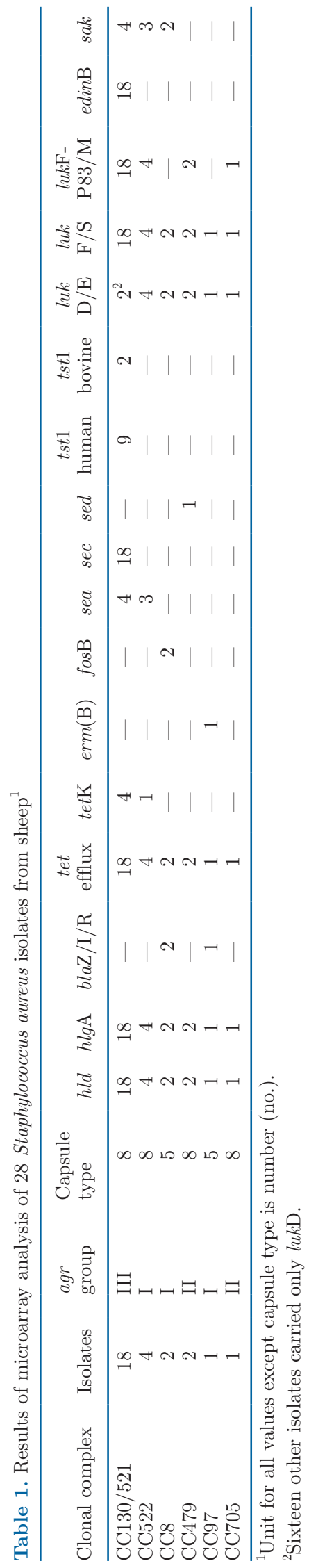


CC479 isolates carried the sed gene. The sec gene was found in all CC130/531 isolates.

Some additional virulence-associated genes could be detected in several isolates. The sak gene encoding staphylokinase was detected in both CC8 isolates, 4 CC130/521 isolates, and 3 CC522 isolates. Hemolysin genes hld and $h l g \mathrm{~A}$ were found in all isolates. All CC130/521 were carriers of edinB, an epidermal cell differentiation inhibitor gene.

All isolates yielded the $3 i c a$ genes (A, C, and D) encoding the intercellular adhesion proteins, but none had the bap gene encoding for biofilm-associated surface protein. Genes encoding efflux systems as well as quaternary ammonium compound resistance protein $\mathrm{A}$ and $\mathrm{C}(q a c \mathrm{~A}, q a c \mathrm{C})$ were not detected.

The ica genes (ica $\mathrm{A}, i c a \mathrm{C}, i c a \mathrm{D})$ were detected in all the isolates. The role of these virulence factors in the pathogenicity of ovine mastitis caused by $S$. aureus has been described (Aguilar et al., 2001; Azara et al., 2017a), in which biofilm formation can limit the effects of antimicrobial agents and make the bacterium extremely difficult to inactivate (Basanisi et al., 2017).

In the present study, the ruminant leukocidin genes $l u k \mathrm{~F}-\mathrm{P} 83$ and $l u k \mathrm{M}$ were found in $89.2 \%$ of $S$. aureus isolates. These genes were found in all isolates that belonged to CC130/521, CC479, CC522, and CC705. The association of a presence of lukM-lukF-P83 with specific ruminant-associated CC, such as CC151, $\mathrm{CC} 133$, CC705, and $\mathrm{CC} 479$, has been reported previously (Schlotter et al., 2012). The higher prevalence of lukM/lukF-P83 genes among sheep than among cattle isolates was reported with regard to nasal carriage (Agabou et al., 2017) and mastitis (Rainard et al., 2003). It has been suggested that $l u k \mathrm{M} / l u k \mathrm{~F}-\mathrm{P} 83$ genes represent an important virulence factor for $S$. aureus causing mastitis in small ruminants (Merz et al., 2016). Bi-component leukotoxins, to which LukM/ LukF'-PV belongs, are cytotoxic to polymorphonuclear cells, reducing the protection of the mammary gland (Rainard et al., 2003). As previously discussed for bovine mastitis, the detection of LukM/LukF'-PV might differentiate native ruminant strains from strains accidentally transferred from humans, and a rapid test for LukM/LukF'-PV might be helpful to identify epidemic ruminant strains (Monecke et al., 2013).

All S. aureus isolates belonging to CC130/521 possessed the toxic shock syndrome toxin gene $t s t 1$, which is in accordance with previous results found for $S$. aureus isolates from sheep (Vautor et al., 2009; Gharsa et al., 2012; Merz et al., 2016). It can be assumed that tst 1 played a role in the pathogenesis of ovine mastitis. At least it does not constitute an immediate hazard to the consumer of raw milk products because it is not resorbed by the mucous membranes of the human di- gestive tract. The effect of staphylococcal enterotoxins would likely be greater.

The enterotoxin gene sec was most commonly detected, followed by sea. The sed gene was detected in 1 isolate. These findings are in agreement with previously reported data (Azara et al., 2017a). The staphylococcal enterotoxin SEA, encoded by sea, was the predominant enterotoxin implicated in staphylococcal food poisoning (Balaban and Rasooly, 2000), which is important because raw milk ingestion is a common practice in Algerian rural areas. The role of these toxins in the IMI is not yet clearly explained. However, it was reported that superantigens were involved in the modulation of the immune response, possibly resulting in colonization of the mammary gland by $S$. aureus and subsequent tissue damage (Fitzgerald et al., 2001; Artursson et al., 2016).

DNA microarrays also allow the detection of other things, such as antibiotic resistance-associated genes. The blaZ gene responsible for resistance to penicillin was detected in CC8 and CC97 isolates. The CC97 isolate harbored the $\mathrm{erm}(\mathrm{B})$ gene responsible for macrolide resistance. The tetK gene, which encodes a tetracycline efflux pump, was detected in $4 \mathrm{CC} 130 / 521$ isolates and 1 CC522 isolate. None of the isolates possessed the van $\mathrm{A}$ gene encoding resistance to vancomycin.

In this study, the detection rate of antibiotic resistance genes was slightly similar to that reported by Azara et al. (2017b). It indicated that the majority of $S$. aureus isolated from ovine mastitis was susceptible to antimicrobials tested (Azara et al., 2017b). According to the protocol for the treatment of sheep mastitis adopted in the area of this study, methicillin is not licensed, which could mean that there is currently no selective pressure favoring MRSA in the study area. A study from Tunisia suggested that antibiotic use tends to be much lower in sheep than in poultry or dairy cows, which may result in a low prevalence of MRSA (Gharsa et al., 2012).

Other antibiotics such as oxytetracycline and penicillin or streptomycin are commonly used against staphylococci involved in sheep mastitis (Attili et al., 2016; Lollai et al., 2016). Tetracycline is generally preferred because of its broad spectrum and delayed elimination time (Ardic et al., 2005). In the study regions, uncontrolled access to veterinary antibiotics (e.g., oxytetracycline) triggered extensive abuse. In sheep breeding, tetracyclines are still used to treat or prevent respiratory infections and lameness. In this study, only $5 S$. aureus isolates were positive for the presence of tet $(\mathrm{K})$ that encodes tetracycline efflux pump. Previous reports indicate the increase of resistance of staphylococci to oxytetracycline in small ruminants in Brazil and Italy (França et al., 2012; Lollai et al., 2016). 
In the current study, S. xylosus and S. haemolyticus isolates possessed the cassette chromosome recombinase genes ccrC and SCCmec-V, respectively. The msrA gene encoding energy-dependent efflux of erythromycin and the far 1 gene encoding fusidic acid resistance were detected in 8 and 4 CNS isolates, respectively. In $S$. aureus and CNS, virulence factors or antibiotic resistance genes can be located on mobile genetic elements.

Coagulase-negative staphylococci gained little attention and were previously considered to be contaminants (Kloos and Schleifer, 1975). However, it was recently demonstrated that CNS are able to carry multiple pathogenic factors such as enterotoxins and TSST-1, and their pathogenicity in animal mastitis has been proven (Onni et al., 2010; El-Ashker et al., 2015). The diversity of CNS species isolated in this study was in accordance with the findings of Onni et al. (2010). They reported that highly prevalent species associated with ovine mastitis were $S$. epidermidis, $S$. chromogenes, $S$. simulans, and S. xylosus (Onni et al., 2010). In S. aureus and CNS, virulence factors or antibiotic resistance genes can be located on mobile genetic elements. Consequently, a horizontal genetic transfer can occur between strains and lead to the acquisition of pathogenicity factors within the staphylococcal population (Omoe et al., 2005). Previous studies suggest that CNS might be considered a reservoir of antibiotic resistance genes for S. aureus (Virdis et al., 2010; França et al., 2012). Furthermore, if no management plan for food safety is enforced, transmission of staphylococci involved in mastitis or their toxins to humans via consumption of animal products can have severe health consequences (El-Ashker et al., 2015).

Considering the little information that exists about the prevalence of mastitis in small ruminants and the lack of knowledge on diversity of staphylococcal isolates circulating among flocks in Algeria, the present findings indicate that staphylococci isolated from sheep mastitis were diverse regarding species and $\mathrm{CC}$ within $S$. aureus and possessed several virulence-associated genes and some antibiotic resistance-associated genes. Staphylococci possessing these genes are considered a potential hazard for farm animals, farmers, and consumers. However, further extensive studies covering more geographical regions are needed to assess the epidemiological risk factors.

\section{ACKNOWLEDGMENTS}

The authors thank Byrgit Hofmann and Peggy Methner at the Institute of Bacterial Infections and Zoonoses, Friedrich-Loeffler-Institut, Jena, Germany, and Elke Müller at Leibniz Institute of Photonic Tech- nology (IPHT), Jena, Germany, for their excellent technical assistance.

\section{REFERENCES}

Agabou, A., Z. Ouchenane, C. Ngba Essebe, S. Khemissi, M. T. E. Chehboub, I. B. Chehboub, A. Sotto, C. Dunyach-Remy, and J. P. Lavigne. 2017. Emergence of nasal carriage of ST80 and ST152 PVL+ Staphylococcus aureus isolates from livestock in Algeria. Toxins (Basel) 9:e303. https://doi.org/10.3390/toxins9100303.

Aguilar, B., B. Amorena, and M. Iturralde. 2001. Effect of slime on adherence of Staphylococcus aureus isolated from bovine and ovine mastitis. Vet. Microbiol. 78:183-191.

Akkou, M., L. Bentayeb, K. Ferdji, B. Medrouh, M. A. Bachtarzi, H. Ziane, R. Kaidi, and M. Tazir. 2018. Phenotypic characterization of Staphylococci causing mastitis in goats and microarray-based genotyping of Staphylococcus aureus isolates. Small Rumin. Res. 169:29-33. https://doi.org/10.1016/j.smallrumres.2018.10.015.

Ardic, N., M. Ozyurt, B. Sareyyupoglu, and T. Haznedaroglu. 2005. Investigation of erythromycin and tetracycline resistance genes in methicillin-resistant staphylococci. Int. J. Antimicrob. Agents 26:213-218. https://doi.org/10.1016/j.ijantimicag.2005.06.013.

Arsenault, J., P. Dubreuil, R. Higgins, and D. Belanger. 2008. Risk factors and impacts of clinical and subclinical mastitis in commercial meat-producing sheep flocks in Quebec, Canada. Prev. Vet. Med. 87:373-393. https://doi.org/10.1016/j.prevetmed.2008.05.006.

Artursson, K., R. Söderlund, L. Liu, S. Monecke, and J. Schelin. 2016. Genotyping of Staphylococcus aureus in bovine mastitis and correlation to phenotypic characteristics. Vet. Microbiol. 193:156-161. https://doi.org/10.1016/j.vetmic.2016.08.012.

Attili, A. R., S. Preziuso, V. N. Ngwa, A. Cantalamessa, M. Moriconi, and V. Cuteri. 2016. Clinical evaluation of the use of enrofloxacin against Staphylococcus aureus clinical mastitis in sheep. Small Rumin. Res. 136:72-77. https://doi.org/10.1016/j.smallrumres.2016 .01 .004 .

Azara, E., C. Longheu, G. Sanna, and S. Tola. 2017a. Biofilm formation and virulence factor analysis of Staphylococcus aureus isolates collected from ovine mastitis. J. Appl. Microbiol. 123:372-379. https://doi.org/10.1111/jam.13502.

Azara, E., M. G. Piras, A. Parisi, and S. Tola. 2017b. Antimicrobial susceptibility and genotyping of Staphylococcus aureus isolates collected between 1986 and 2015 from ovine mastitis. Vet. Microbiol. 205:53-56. https://doi.org/10.1016/j.vetmic.2017.05.006.

Balaban, N., and A. Rasooly. 2000. Staphylococcal enterotoxins. Int. J. Food Microbiol. 61:1-10.

Bar-Gal, G. K., S. E. Blum, L. Hadas, R. Ehricht, S. Monecke, and G. Leitner. 2015. Host-specificity of Staphylococcus aureus causing intramammary infections in dairy animals assessed by genotyping and virulence genes. Vet. Microbiol. 176:143-154. https://doi.org/ 10.1016/j.vetmic.2015.01.007.

Basanisi, M. G., G. La Bella, G. Nobili, I. Franconieri, and G. La Salandra. 2017. Genotyping of methicillin-resistant Staphylococcus aureus (MRSA) isolated from milk and dairy products in South Italy. Food Microbiol. 62:141-146. https://doi.org/10.1016/j.fm 2016.10.020.

Ben Zakour, N. L., D. E. Sturdevant, S. Even, C. M. Guinane, C. Barbey, P. D. Alves, M. F. Cochet, M. Gautier, M. Otto, J. R. Fitzgerald, and Y. Le Loir. 2008. Genome-wide analysis of ruminant Staphylococcus aureus reveals diversification of the core genome. J. Bacteriol. 190:6302-6317. https://doi.org/10.1128/JB .01984-07.

Bergonier, D., R. de Cremoux, R. Rupp, G. Lagriffoul, and X. Berthelot. 2003. Mastitis of dairy small ruminants. Vet. Res. 34:689-716. https://doi.org/10.1051/vetres:2003030.

Carfora, V., G. Giacinti, D. Sagrafoli, N. Marri, G. Giangolini, P. Alba, F. Feltrin, L. Sorbara, R. Amoruso, A. Caprioli, S. Amatiste, and A. Battisti. 2016. Methicillin-resistant and methicillin-susceptible Staphylococcus aureus in dairy sheep and in-contact humans: An intra-farm study. J. Dairy Sci. 99:4251-4258. https://doi.org/ 10.3168/jds.2016-10912. 
Caruso, M., L. Latorre, G. Santagada, R. Fraccalvieri, A. Miccolupo, R. Sottili, L. Palazzo, and A. Parisi. 2016. Methicillin-resistant Staphylococcus aureus (MRSA) in sheep and goat bulk tank milk from Southern Italy. Small Rumin. Res. 135:26-31. https://doi .org/10.1016/j.smallrumres.2015.12.023.

Chua, K. Y., B. P. Howden, J. H. Jiang, T. Stinear, and A. Y. Peleg. 2014. Population genetics and the evolution of virulence in Staphylococcus aureus. Infect. Genet. Evol. 21:554-562. https://doi.org/ 10.1016/j.meegid.2013.04.026.

Dore, S., M. Liciardi, S. Amatiste, S. Bergagna, G. Bolzoni, V. Caligiuri, A. Cerrone, G. Farina, C. O. Montagna, M. A. Saletti, M. L. Scatassa, G. Sotgiu, and E. A. Cannas. 2016. Survey on small ruminant bacterial mastitis in Italy, 2013-2014. Small Rumin. Res. 141:91-93. https://doi.org/10.1016/j.smallrumres.2016.07.010.

El-Adawy, H., M. Ahmed, H. Hotzel, S. Monecke, J. Schulz, J. Hartung, R. Ehricht, H. Neubauer, and H. M. Hafez. 2016. Characterization of methicillin-resistant Staphylococcus aureus isolated from healthy turkeys and broilers using DNA microarrays. Front. Microbiol. 7:2019. https://doi.org/10.3389/fmicb.2016.02019.

El-Ashker, M., M. Gwida, H. Tomaso, S. Monecke, R. Ehricht, F. El-Gohary, and H. Hotzel. 2015. Staphylococci in cattle and buffaloes with mastitis in Dakahlia Governorate. Egypt. J. Dairy Sci. 98:7450-7459. https://doi.org/10.3168/jds.2015-9432.

FAO (Food and Agriculture Organization of the United Nations). 2015. FAO Statistical Pocketbook. FAO, Rome, Italy.

Fitzgerald, J. R., S. R. Monday, T. J. Foster, G. A. Bohach, P. J. Hartigan, W. J. Meaney, and C. J. Smyth. 2001. Characterization of a putative pathogenicity island from bovine Staphylococcus aureus encoding multiple superantigens. J. Bacteriol. 183:63-70. https:// doi.org/10.1128/JB.183.1.63-70.2001.

França, C. A., R. M. Peixoto, M. B. Cavalcante, N. F. Melo, C. J. B. Oliveira, J. A. Veschi, R. A. Mota, and M. M. Costa. 2012. Antimicrobial resistance of Staphylococcus spp. from small ruminant mastitis in Brazil. Pesqui. Vet. Bras. 32:747-753.

Gelasakis, A. I., V. S. Mavrogianni, I. G. Petridis, N. G. C. Vasileiou, and G. C. Fthenakis. 2015. Mastitis in sheep-The last 10 years and the future of research. Vet. Microbiol. 181:136-146. https:// doi.org/10.1016/j.vetmic.2015.07.009.

Gharsa, H., K. Ben Slama, C. Lozano, E. Gomez-Sanz, N. Klibi, R. Ben Sallem, P. Gomez, M. Zarazaga, A. Boudabous, and C. Torres. 2012. Prevalence, antibiotic resistance, virulence traits and genetic lineages of Staphylococcus aureus in healthy sheep in Tunisia. Vet. Microbiol. 156:367-373. https://doi.org/10.1016/j.vetmic 2011.11.009.

Giadinis, N. D., G. Arsenos, P. Tsakos, V. Psychas, C. I. Dovas, E. Papadopoulos, H. Karatzias, and G. C. Fthenakis. 2012. "Milkdrop syndrome of ewes": Investigation of the causes in dairy sheep in Greece. Small Rumin. Res. 106:33-35. https://doi.org/10.1016/ j.smallrumres.2012.04.018.

Goñi, P., Y. Vergara, J. Ruiz, I. Albizu, J. Vila, and R. Gomez-Lus. 2004. Antibiotic resistance and epidemiological typing of Staphylococcus aureus strains from ovine and rabbit mastitis. Int. J. Antimicrob. Agents 23:268-272. https://doi.org/10.1016/j.ijantimicag 2003.07.016.

Gonzalo, C., A. Ariznabarreta, J. A. Carriedo, and F. San Primitivo. 2002. Mammary pathogens and their relationship to somatic cell count and milk yield losses in dairy ewes. J. Dairy Sci. 85:14601467. https://doi.org/10.3168/jds.S0022-0302(02)74214-8.

Gonzalo, C., J. A. Tardaguila, L. F. De La Fuente, and F. San Primitivo. 2004. Effects of selective and complete dry therapy on prevalence of intramammary infection and on milk yield in the subsequent lactation in dairy ewes. J. Dairy Res. 71:33-38.

Harkat, S., A. Laoun, R. Benali, D. Outayeb, M. Ferrouk, A. Maftah, A. Da Silva, and M. Lafri. 2015. Phenotypic characterization of the major sheep breed in Algeria. Rev. Med. Vet. (Toulouse) 166:138-147.

International Dairy Federation. 1981. Laboratory Methods for Use in Mastitis Work. IDF, Brussels, Belgium.

Kennedy, A. D., M. Otto, K. R. Braughton, A. R. Whitney, L. Chen, B. Mathema, J. R. Mediavilla, K. A. Byrne, L. D. Parkins, F. C.
Tenover, B. N. Kreiswirth, J. M. Musser, and F. R. DeLeo. 2008. Epidemic community-associated methicillin-resistant Staphylococcus aureus: Recent clonal expansion and diversification. Proc. Natl. Acad. Sci. USA 105:1327-1332. https://doi.org/10.1073/ pnas. 0710217105.

Kloos, W. E., and K. H. Schleifer. 1975. Simplified scheme for routine identification of human Staphylococcus species. J. Clin. Microbiol. $1: 82-88$.

Leitner, G., N. Silanikove, and U. Merin. 2008. Estimate of milk and curd yield loss of sheep and goats with intrammamary infection and its relation to somatic cell count. Small Rumin. Res. 74:221225. https://doi.org/10.1016/j.smallrumres.2007.02.009.

Lollai, S. A., M. Ziccheddu, C. Di Mauro, D. Manunta, A. Nudda, and G. Leori. 2008. Profile and evolution of antimicrobial resistance of ovine mastitis pathogens (1995-2004). Small Rumin. Res. 74:249254. https://doi.org/10.1016/j.smallrumres.2007.04.007.

Lollai, S. A., M. Ziccheddu, I. Dupre, and D. Piras. 2016. Characterization of resistance to tetracyclines and aminoglycosides of sheep mastitis pathogens: Study of the effect of gene content on resistance. J. Appl. Microbiol. 121:941-951. https://doi.org/10.1111/ jam. 13229

Mavrogianni, V. S., P. I. Menzies, I. A. Fragkou, and G. C. Fthenakis. 2011. Principles of mastitis treatment in sheep and goats. Vet. Clin. North Am. Food Anim. Pract. 27:115-120. https://doi.org/ 10.1016/j.cvfa.2010.10.010.

McMillan, K., S. C. Moore, C. M. McAuley, N. Fegan, and E. M. Fox. 2016. Characterization of Staphylococcus aureus isolates from raw milk sources in Victoria, Australia. BMC Microbiol. 16:169. https: //doi.org/10.1186/s12866-016-0789-1.

Menzies, P. I., and S. Z. Ramanoon. 2001. Mastitis of sheep and goats. Vet. Clin. North Am. Food Anim. Pract. 17:333-358. https://doi .org/10.1016/S0749-0720(15)30032-3.

Merz, A., R. Stephan, and S. Johler. 2016. Staphylococcus aureus isolates from goat and sheep milk seem to be closely related and differ from isolates detected from bovine milk. Front. Microbiol. 7:319. https://doi.org/10.3389/fmicb.2016.00319.

Monecke, S., and R. Ehricht. 2005. Rapid genotyping of methicillin-resistant Staphylococcus aureus (MRSA) isolates using miniaturised oligonucleotide arrays. Clin. Microbiol. Infect. 11:825-833. https:/ /doi.org/10.1111/j.1469-0691.2005.01243.x.

Monecke, S., D. Gavier-Widen, H. Hotzel, M. Peters, S. Guenther, A. Lazaris, I. Loncaric, E. Müller, A. Reissig, A. Ruppelt-Lorz, A. C. Shore, B. Walter, D. C. Coleman, and R. Ehricht. 2016. Diversity of Staphylococcus aureus isolates in European wildlife. PLoS One 11:e0168433.

Monecke, S., P. Kuhnert, H. Hotzel, P. Slickers, and R. Ehricht. 2007. Microarray based study on virulence-associated genes and resistance determinants of Staphylococcus aureus isolates from cattle. Vet. Microbiol. 125:128-140. https://doi.org/10.1016/j.vetmic .2007.05.016.

Monecke, S., E. Müller, J. Buechler, J. Rejman, B. Stieber, P. Akpaka, D. Bandt, R. Burris, G. Coombs, G. Hidalgo-Arroyo, P. Hughes, A. Kearns, S. M. Abos, B. Pichon, L. Skakni, B. Soderquist, and R. Ehricht. 2013. Rapid detection of Panton-Valentine leukocidin in Staphylococcus aureus cultures by use of a lateral flow assay based on monoclonal antibodies. J. Clin. Microbiol. 51:487-495. https://doi.org/10.1128/JCM.02285-12.

Monecke, S., P. Slickers, and R. Ehricht. 2008. Assignment of Staphylococcus aureus isolates to clonal complexes based on microarray analysis and pattern recognition. FEMS Immunol. Med. Microbiol. 53:237-251. https://doi.org/10.1111/j.1574-695X.2008.00426.x.

Mørk, T., T. Tollersrud, B. Kvitle, H. J. Jorgensen, and S. Waage. 2005. Genetic diversity of Staphylococcus aureus isolated from ovine intramammary infections in Norway. Vet. Microbiol. 106:265-273. https://doi.org/10.1016/j.vetmic.2004.12.020.

Obaidat, M. M., A. E. Bani Salman, and A. A. Roess. 2018. High prevalence and antimicrobial resistance of mecA Staphylococcus aureus in dairy cattle, sheep, and goat bulk tank milk in Jordan. Trop. Anim. Health Prod. 50:405-412. https://doi.org/10.1007/ s11250-017-1449-7. 
Oliver, S. P. 2004. Microbiological Procedures for the Diagnosis of Bovine Udder Infection and Determination of Milk Quality. National Mastitis Council, Verona, WI.

Omoe, K., D. L. Hu, H. Takahashi-Omoe, A. Nakane, and K. Shinagawa. 2005. Comprehensive analysis of classical and newly described staphylococcal superantigenic toxin genes in Staphylococcus aureus isolates. FEMS Microbiol. Lett. 246:191-198. https://doi.org/10 .1016/j.femsle.2005.04.007

Onni, T., G. Sanna, G. P. Cubeddu, G. Marogna, S. Lollai, G. Leori, and S. Tola. 2010. Identification of coagulase-negative staphylococci isolated from ovine milk samples by PCR-RFLP of $16 \mathrm{~S}$ rRNA and gap genes. Vet. Microbiol. 144:347-352. https://doi .org/10.1016/j.vetmic.2010.01.016.

Ouchenane, Z., F. Smati, J. M. Rolain, and D. Raoult. 2011. Molecular characterization of methicillin-resistant Staphylococcus aureus isolates in Algeria. Pathol. Biol. (Paris) 59:e129-e132. https://doi .org/10.1016/j.patbio.2009.11.004.

Porrero, M. C., H. Hasman, A. I. Vela, J. F. Fernandez-Garayzabal, L. Dominguez, and F. M. Aarestrup. 2012. Clonal diversity of Staphylococcus aureus originating from the small ruminants goats and sheep. Vet. Microbiol. 156:157-161. https://doi.org/10.1016/ j.vetmic.2011.10.015.

Quinn, P. J., M. E. Carter, B. K. Markey, and G. R. Carter. 1994. Clinical Veterinary Microbiology. Mosby, London, UK.

Rainard, P., J. C. Corrales, M. B. Barrio, T. Cochard, and B. Poutrel. 2003. Leucotoxic activities of Staphylococcus aureus strains isolated from cows, ewes, and goats with mastitis: Importance of LukM/ LukF'-PV leukotoxin. Clin. Diagn. Lab. Immunol. 10:272-277.

Ramdani-Bouguessa, N., M. Bes, H. Meugnier, F. Forey, M. E. Reverdy, G. Lina, F. Vandenesch, M. Tazir, and J. Etienne. 2006. Detection of methicillin-resistant Staphylococcus aureus strains resistant to multiple antibiotics and carrying the Panton-Valentine leukocidin genes in an Algiers hospital. Antimicrob. Agents Chemother. 50:1083-1085. https://doi.org/10.1128/AAC.50.3.1083-1085.2006.

Rebiahi, S. A., D. E. Abdelouahid, M. Rahmoun, S. Abdelali, and H. Azzaoui. 2011. Emergence of vancomycin-resistant Staphylococcus aureus identified in the Tlemcen university hospital (North-West Algeria). Med. Mal. Infect. 41:646-651. https://doi.org/10.1016/j .medmal.2011.09.010.

Schaumburg, F., M. Pauly, E. Anoh, A. Mossoun, L. Wiersma, G. Schubert, A. Flammen, A. S. Alabi, J. J. Muyembe-Tamfum, M. P. Grobusch, S. Karhemere, C. Akoua-Koffi, E. Couacy-Hymann, P. G. Kremsner, A. Mellmann, K. Becker, F. H. Leendertz, and G. Peters. 2015. Staphylococcus aureus complex from animals and humans in three remote African regions. Clin. Microbiol. Infect. 21:345.e1-345.e8. https://doi.org/10.1016/j.cmi.2014.12.001.

Schlotter, K., R. Ehricht, H. Hotzel, S. Monecke, M. Pfeffer, and K. Donat. 2012. Leukocidin genes lukF-P83 and lukM are associated with Staphylococcus aureus clonal complexes 151, 479 and 133 isolated from bovine udder infections in Thuringia, Germany. Vet. Res. 43:42. https://doi.org/10.1186/1297-9716-43-42.

Smith, E. M., P. F. Needs, G. Manley, and L. E. Green. 2014. Global distribution and diversity of ovine-associated Staphylococcus aureus. Infect. Genet. Evol. 22:208-215. https://doi.org/10.1016/j .meegid.2013.09.008.

Smyth, D. S., E. J. Feil, W. J. Meaney, P. J. Hartigan, T. Tollersrud, J. R. Fitzgerald, M. C. Enright, and C. J. Smyth. 2009. Molecular genetic typing reveals further insights into the diversity of animalassociated Staphylococcus aureus. J. Med. Microbiol. 58:1343-1353. https://doi.org/10.1099/jmm.0.009837-0.

van Belkum, A.. D. C. Melles, S. V. Snijders, W. B. van Leeuwen, H. F. Wertheim, J. L. Nouwen, H. A. Verbrugh, and J. Etienne. 2006. Clonal distribution and differential occurrence of the enterotoxin gene cluster, egc, in carriage- versus bacteremia-associated isolates of Staphylococcus aureus. J. Clin. Microbiol. 44:1555-1557. https:/ /doi.org/10.1128/JCM.44.4.1555-1557.2006.

Vautor, E., H. Carsenti-Dellamonica, M. Sabah, G. Mancini, M. Pepin, and P. Dellamonica. 2007. Characterization of Staphylococcus aureus isolates recovered from dairy sheep farms (agr group, adherence, slime, resistance to antibiotics). Small Rumin. Res. 72:197-199. https://doi.org/10.1016/j.smallrumres.2006.08.011.

Vautor, E., J. Cockfield, C. Le Marechal, Y. Le Loir, M. Chevalier, D A. Robinson, R. Thiery, and J. Lindsay. 2009. Difference in virulence between Staphylococcus aureus isolates causing gangrenous mastitis versus subclinical mastitis in a dairy sheep flock. Vet. Res. 40:56. https://doi.org/10.1051/vetres/2009039.

Vautor, E., C. Jay, N. Chevalier, N. Visomblin, G. Vernet, and M. Pepin. 2005. Characterization of 26 isolates of Staphylococcus aureus, predominantly from dairy sheep, using four different techniques of molecular epidemiology. J. Vet. Diagn. Invest. 17:363-368. https:/ /doi.org/10.1177/104063870501700411.

Viguier, C., S. Arora, N. Gilmartin, K. Welbeck, and R. O'Kennedy. 2009. Mastitis detection: Current trends and future perspectives Trends Biotechnol. 27:486-493. https://doi.org/10.1016/j.tibtech .2009.05.004.

Virdis, S., C. Scarano, F. Cossu, V. Spanu, C. Spanu, and E. P. De Santis. 2010. Antibiotic resistance in Staphylococcus aureus and coagulase negative Staphylococci isolated from goats with subclinical mastitis. Vet. Med. Int. 2010:517060. https://doi.org/10.4061/ $2010 / 517060$.

\section{ORCIDS}

Hosny El-Adawy 주 https://orcid.org/0000-0002-8585-4237 